\title{
Perbanyakan Jamur Trichoderma sp pada Beberapa Media
}

\author{
Dewi Novianti \\ e-mail: dewinovianti1980@gmail.com \\ Program Studi Biologi, Fakultas Matematika dan Ilmu Pengetahuan Alam \\ Universitas PGRI Palembang
}

\begin{abstract}
This study aims to determine the media suitable for growth and propagation of Trichoderma sp. Trichoderma sp is a fungus that can be used as a biological agent against plant pathogens while improving the growth and development of plants. The study was prepared based on a complete randomized design pattern (RAL) consisting of six treatments and each treatment was repeated four times. The tested treatments were Media PDA $\left(\mathrm{M}_{1}\right)$, rice medium $\left(\mathrm{M}_{2}\right)$, corn medium $\left(\mathrm{M}_{3}\right)$, green bean medium $\left(\mathrm{M}_{4}\right)$, sawdust media $\left(\mathrm{M}_{5}\right)$, and bran medium $\left(\mathrm{M}_{6}\right)$. The parameters observed in this study are two, namely the diameter of colony growth and conidia density. Initial isolates of Trichoderma sp were used $8.5 \times 10^{6}$ conidia/mg. The results showed the multiplication of Trichoderma sp on various media have an effect on to growth of diameter and density of Trichoderma sp colony. Trichoderma sp can grow on all treatment mediums. Media bran is the highest medium density conidia than other media.
\end{abstract}

Keywords: Propagation, Trichoderma sp, media.

\begin{abstract}
ABSTRAK
Penelitian ini bertujuan untuk mengetahui media yang cocok untuk pertumbuhan dan perbanyakan jamur Trichoderma sp. Trichoderma sp merupakan jamur yang dapat dijadikan agen hayati terhadap patogen tanaman sekaligus meningkatkan pertumbuhan dan perkembangan tanaman. Penelitian disusun berdasarkan pola rancangan acak lengkap (RAL) yang terdiri dari enam perlakuan dan setiap perlakuan diulang sebanyak empat kali. Perlakuan yang diujikan adalah Media PDA $\left(\mathrm{M}_{1}\right)$, media beras $\left(\mathrm{M}_{2}\right)$, media jagung $\left(\mathrm{M}_{3}\right)$, media kacang hijau $\left(\mathrm{M}_{4}\right)$, media serbuk gergaji $\left(\mathrm{M}_{5}\right)$, dan media dedak $\left(\mathrm{M}_{6}\right)$. Parameter yang diamati dalam penelitian ini ada dua yaitu diameter pertumbuhan koloni dan kerapatan konidia. Isolat awal Trichoderma sp yang digunakan sebanyak $8,5 \times 10^{6}$ konidia/mg. Hasil penelitian menunjukkan perbanyakan Trichoderma sp pada berbagai media berpengaruh terhadap pertumbuhan diameter dan kerapatan koloni Trichoderma sp. Trichoderma sp dapat tumbuh pada semua media perlakuan. Media dedak merupakan media yang paling tinggi kerapatan konidia dibandingkan media lainnya.
\end{abstract}

Kata Kunci: Perbanyakan, Trichoderma sp, media. 


\section{PENDAHULUAN}

Penyakit tanaman merupakan faktor pembatas terhadap pertumbuhan dan perkembangan tanaman. Metode pengendalian yang sering dilakukan oleh para petani untuk mengatasi masalah tersebut yaitu penggunaan bahan pestisida sintetik yang melebihi dosis anjuran dan digunakan secara terusmenerus sehingga mengakibatkan akumulasi pestisida di tanah. Akumulasi pestisida yang tinggi menimbulkan dampak negatif terhadap lingkungan bahkan ke tingkat konsumen, berkurangnya mikroorganisme tanah, dan kerentanan tanaman (Miftakhun, 2017). Suwahyono (2009), menyatakan bahwa penggunaan pestisida sintetik dapat membahayakan keselamatan hayati termasuk manusia dan keseimbangan ekosistem. Oleh sebab itu, saat ini metode pengendalian telah diarahkan pada pengendalian hayati/biologis.

Pengendalian hayati (biological control) merupakan cara pengendalian penyakit yang melibatkan manipulasi musuh alami yang menguntungkan untuk memperoleh pengurangan jumlah populasi dan status hama dan penyakit di lapangan. Jamur entomopatogenik dan jamur antagonis merupakan beberapa jenis agens hayati yang bisa dimanfaatkan dalam upaya pengendalian hayati. Beberapa alasan kenapa jamur tersebut menjadi pilihan sebagai pengendali hayati karena jamur-jamur tersebut mempunyai kapasitas reproduksi yang tinggi, mempunyai siklus hidup yang pendek, dapat membentuk spora yang mampu bertahan lama di alam bahkan dalam kondisi ekstrim, disamping itu juga relatif aman digunakan, cukup mudah diproduksi, cocok dengan berbagai insektisida, dan kemungkinan menimbulkan resistensi sangat kecil (Kansrini, 2015).

Trichoderma sp merupakan jamur yang dapat menjadi agen biokontrol karena bersifat antagonis bagi jamur lainnya.Aktivitas antagonis tersebut meliputi persaingan, parasitisme, predasi, atau pembentukkan toksin seperti antibiotik. Trichoderma sp merupakan jamur yang habitatnya di tanah, termasuk class Ascomycetes yang mempunyai spora hijau. Jamur ini mempunyai potensi degradasi dekomposisi berbagai macam substrat heterogen di tanah, interaksi positif dengan inang, memproduksi enzim untuk perbaikan nutrisi bagi tanaman. Spesies Trichoderma diantaranya adalah Trichoderma reesei, Trichoderma viride, dan Trichoderma harzianum (Schuster dan Schmoll, 2010). Trichoderma sp efektif menghambat pertumbuhan Sclerotinia sclerotiorum, Fusarium oxysprum, dan Altenaria brassicicola yang merupakan patogen tanaman (Manokaran, 2016). Hasil penelitian Alfizar $d k k$ (2013), Trichoderma sp dapat menghambat pertumbuhan cendawan patogen $C$. capsici, Fusarium sp, dan S. rolfsii secara in vitro. Daya hambat Trichoderma $\mathrm{sp}$ yang paling tinggi terdapat pada patogen C. capsici, diikuti dengan daya hambat terhadap patogen Fusarium sp dan $S$. rolfsii.

Selain sebagai agens hayati terhadap penyakit tanaman, Trichoderma sp dapat meningkatkan pertumbuhan dan perkembangan tanaman yang diinfeksinya. Penelitian Shofiyani dan Suyadi (2014), perlakuan agensis hayati Trichoderma dengan berbagai dosis berpengaruh nyata terhadap parametar jumlah daun dan jumlah umbi, namun tidak berpengaruh nyata terhadap tinggi tanaman dan bobot umbi bawang merah. Perlakuan Trichoderma viridae pada kisaran dosis $40 \mathrm{~g} /$ lubang tanam memberikan pengaruh terbaik terhadap pertumbuhan tanaman bawang merah selama penelitian. Keunggulan jamur Trichoderma sp sebagai agensia pengendali hayati dibandingkan dengan jenis fungisida kimia sintetik adalah 
selain mampu mengendalikan jamur patogen dalam tanah, ternyata juga dapat mendorong adanya fase revitalisasi tanaman. Revitalisasi ini terjadi karena adanya mekanisme interaksi antara tanaman dan agensia aktif dalam memacu hormon pertumbuhan tanaman (Nasahi, 2010). Agensia hayati Trichoderma ( T.harzianum dan $T$. viride) yang diaplikasikan dengan pencelupan dan penyiraman ternyata berpengaruh pada peningkatan jumlah daun pada bibit selama penelitian, dan tidak berpengaruh pada tinggi tanaman maupun diameter batang pada masing-masing perlakuan. Namun demikian pemberian Trichoderma mampu memberikan pertumbuhan yang lebih baik bila dibandingkan kontrol. Trichoderma harzianum dan Trichoderma viride mampu mengkolonisasi akar bibit tanaman pisang dan bersifat endofit pada tanaman pisang mas hasil kultur in vitro (Shofiyani dan Budi, 2013). Aplikasi Trichoderma sp dengan cara perlakuan benih atau introduksi massal di daerah rizosfir sebelum tanam menunjukkan keberhasilan yang baik dalam penekanan berbagai penyakit dan peningkatan pertumbuhan tanaman (Nurbailis dan Martinius, 2011).

Penggunaan agen hayati untuk pengendalian penyakit dirasakan sangat lambat perkembangannya karena terbatasnya agen hayati yang diproduksi secara massal dan dapat digunakan secara komersial, sehingga diperlukan teknologi untuk produksi massal Trichoderma $\mathrm{sp}$ pada beberapa macam media (Dewi, 2006 dalam Wijaya $d k k$., 2011). Terdapat permasalahan yang timbul bagaimana mendapatkan jamur Trichoderma $\mathrm{sp}$ dalam jumlah yang besar serta murah. Perbanyakan massal dapat dilakukan dengan menggunakan media buatan yang berisi nutrisi yang dibutuhkan untuk pertumbuhan Trichoderma sp. Hasil penelitian Urailal $d k k$ (2012), dedak, beras, serbuk gergaji dan sekam padi dapat digunakan sebagai media perbanyakan Trichoderma sp. Bahanbahan tersebut mengandung karbohidrat, serat, nitrogen, posfat, kalium, yang diperlukan untuk pertumbuhan dan perkembangan Trichoderma sp. Berdasarkan hal tersebut maka perlu dilakukan pengujian keefektifan perbanyakan Trichoderma sp pada berbagai media tumbuh sehingga diketahui media yang cocok untuk pertumbuhan dan perbanyakan Trichoderma sp secara massal.

\section{BAHAN DAN METODE}

Alat yang digunakan dalam penelitian ini diantaranya adalah: autoklaf, cawan petri, mikroskop, lampu bunsen, jarum ose, tabung reaksi, LAF, saringan, pisau, beaker glass, timbangan, kompor gas, panci, kukusan, baskom, gelas ukur, haemacytometer, erlenmeyer, paper dish. Sedangkan bahan yang digunakan dalam penelitian ini adalah: isolat Trichoderma sp, media PDA alami, beras, jagung, kacang hijau, serbuk gergaji, dedak, aquades, dan alkohol.

Penelitian ini merupakan penelitian eksperimen di laboratorium dengan kondisi steril, dan homogen, menggunakan Rancangan Acak Lengkap dengan menggunakan 6 perlakuan media. Setiap perlakuan terdiri atas 4 kali ulangan. Masing-masing perlakuan sebagai berikut:

$\mathrm{M}_{1}=$ Media PDA

$\mathrm{M}_{2}=$ Media Beras

$\mathrm{M}_{3}=$ Media Jagung

$\mathrm{M}_{4}=$ Media Kacang Hijau

$\mathrm{M}_{5}=$ Media Serbuk Gergaji

$\mathrm{M}_{6}=$ Media Dedak

Pelaksanaan penelitian terdiri dari: Pembuatan Media PDA sintetik sekaligus sebagai media perlakuan (kontrol), peremajaan Trichoderma sp, pembuatan media perlakuan, inokulasi, dan terakhir pengamatan. Pembuatan media beras 
dengan cara: dicuci beras sebanyak 100 gr lalu direndam dalam baskom berisi air panas selama 15 menit, setelah itu dikukus selama 30 menit lalu didinginkan, dimasukkan 25 gr media ke dalam cawan petri lalu dibungkus dengan plastic wrap, lalu disterilkan ke dalam autoklaf. Untuk pembuatan media jagung, kacang hijau, serbuk gergaji, dan dedak caranya sama dengan cara pembuatan media beras tersebut di atas. Sedangkan media PDA yang digunakan adalah media PDA sintetik. Isolat awal Trichoderma sp yang digunakan sebanyak $8,5 \times 10^{6} \mathrm{konidia} / \mathrm{mg}$. Paper dish yang sudah dicelupkan isolat diletakkan di bagian tengah pada masingmasing media perlakuan, lalu diinkubasi dan siap untuk diamati. Variabel pengamatan ada dua yaitu diameter koloni dan kerapatan konidia. Pengukuran diameter koloni menggunakan jangka sorong sebanyak 4 kali pengukuran. Kerapatan konidia Trichoderma sp pada masing-masing media perlakuan, dihitung berdasarkan rumus:

$$
\mathrm{K}=\frac{t \times p \quad t \times p}{0,25 \times n 0,25 \times n} \times 10^{6}
$$

Keterangan:

$\mathrm{K}=$ Kerapatan konidia (konidia/mg)

$\mathrm{p}=$ Faktor pengenceran

$\mathrm{t}=$ Jumlah konidia

$\mathrm{n}=$ Jumlah kotak yang di amati

$0,25=$ Konstanta

$10^{6}=$ Konstanta kerapatan konidia

(Sumber: Surtikanti dan Juniarsih, 2010)

Data dianalisis menggunakan analisis sidik ragam. Jika perlakuan berpengaruh nyata maka dilakukan uji lanjut.

\section{HASIL DAN PEMBAHASAN}

Pengujian pengaruh faktor perlakuan berbagai media terhadap keragaman data hasil pengukuran diameter koloni Trichoderma sp dapat dilihat pada Tabel 1 di bawah ini.

Tabel 1. Hasil Analisis Sidik Ragam Diameter Koloni Jamur Trichoderma sp pada Berbagai Media Perlakuan.

\begin{tabular}{|c|l|l|l|l|l|l|}
\hline & & & & & \multicolumn{2}{|c|}{$\mathrm{F}^{\text {Tabel }}$} \\
Sumber Ragam & DB & JK & KT & \multirow{2}{*}{ F $^{\text {Hitung }}$} & & \multirow{2}{*}{$1 \%$} \\
& & & & & & \\
& & & & & $5 \%$ & \\
\hline Perlakuan & 5 & 28,6 & 5,7 & & & \\
\hline Galat & 18 & 1,8 & 0,1 & $57,14 * *$ & 2,8 & 4,3 \\
\hline Total & 24 & 30,4 & 5,8 & & & \\
\hline
\end{tabular}

Pada Tabel 1 Hasil Ansira menunjukkan perbanyakan Trichoderma sp pada beberapa media perlakuan berpengaruh sangat nyata terhadap diameter pertumbuhan koloni Trichoderma sp.

Tabel 2. Diameter Koloni Trichoderma $\mathrm{sp}$

\begin{tabular}{|l|c|} 
Perlakuan Media & $\begin{array}{c}\text { Rata-rata } \\
\text { Diameter koloni } \\
(\mathrm{cm})\end{array}$ \\
\hline PDA & $\mathbf{9}$ c \\
\hline Beras & $\mathbf{9}$ c \\
\hline Jagung & $\mathbf{9}$ c \\
\hline Kacang Hijau & 7,5 b \\
\hline Serbuk Gergaji & $\mathbf{6 , 2}$ a \\
\hline Dedak & $\mathbf{9}$ c \\
\hline \multicolumn{2}{|c|}{ BNT $_{0,05}=0,47$} \\
\hline
\end{tabular}

Tabel 2 menunjukkan diameter koloni Trichoderma sp pada beberapa media 
perlakuan didapatkan diameter yang sama yaitu $9 \mathrm{~cm}$ tidak berbeda nyata pada media PDA, media beras, media jagung, dan media dedak. Pada beberapa media tersebut diameter Trichoderma sp sama secara visual, tetapi setelah dihitung kerapatan konidianya ternyata berbeda. Secara visual ketebalan miselianya juga berbeda. Pada media serbuk gergaji miselianya lebih sedikit dibandingkan media lainnya, sedangkan miselia terbanyak atau paling tebal terdapat pada media PDA dan dedak. Diameter Trichoderma sp terendah pada media serbuk gergaji yaitu $6,2 \mathrm{~cm}$ berbeda nyata dengan diameter Trichoderma sp pada media lainnya, hal ini karena serbuk gergaji mengandung sedikit karbohidrat dan kadar air dibandingkan dengan media perlakuan lainnya. Secara visual dapat dilihat pada media serbuk gergaji terlalu kering dibandingkan dengan media lainnya. Hasil penelitian Gusnawaty et al (2013), media serbuk gergaji kurang baik digunakan untuk menumbuhkan jamur karena kandungan $\mathrm{C}$ nya tidak terlalu mencukupi untuk pertumbuhan jamur. Berdasarkan pengamatan bahwa media perlakuan mengalami perubahan warna pada 4 hsi dan 7 hsi. Warna media berubah kehijauan karena ditumbuhi jamur antagonis Trichoderma sp. Pada 4 hsi jamur tumbuh di atas permukaan media, sehingga media kelihatan berubah warna menjadi hijau dan 5 hsi jamur sudah mulai menyebar ke bawah. Pada 7 hsi media kelihatan menghijau karena Trichoderma sp sudah tumbuh merata. Pada pengamatan mikroskopis terlihat Trichoderma sp memiliki konidia berwarna hijau dan bentuknya bulat transparan, memiliki hifa, berdinding halus, dan bercabang banyak. Pada Trichoderma sp yang dikultur, morfologi koloninya bergantung pada media tempat bertumbuh. Pada media yang nutrisinya terbatas, koloninya tampak transparan, sedangkan pada media yang nutrisinya lebih banyak maka koloninya dapat terlihat lebih hijau. Trichoderma sp dapat dibiakkan pada beberapa media tumbuh. Hasil penelitian Wijaya $d k k$ (2011), Trichoderma sp berwarna hijau tumbuh merata pada hari ke-7 setelah inkubasi pada media bekatul, media beras jagung, media sekam, media bekatul sekam, dan media beras jagung.

Tabel 3. Hasil Analisis Sidik Ragam Kerapatan Konidia Jamur Trichoderma sp pada Berbagai Media

\begin{tabular}{|c|c|c|c|c|c|c|}
\hline \multirow{3}{*}{ Sumber Ragam } & \multirow{3}{*}{ DB } & \multirow{3}{*}{ JK } & \multirow{3}{*}{ KT } & \multirow{3}{*}{$\mathrm{F}^{\text {Hitung }}$} & \multicolumn{2}{|c|}{$\mathrm{F}^{\text {Tabel }}$} \\
\hline & & & & & & $1 \%$ \\
\hline & & & & & $5 \%$ & \\
\hline Perlakuan & 5 & 49,7 & 9,9 & \multirow{3}{*}{$15,0 * *$} & \multirow{3}{*}{2,77} & \multirow{3}{*}{$\begin{array}{c}4,2 \\
5\end{array}$} \\
\hline Galat & 18 & 11,9 & 0,7 & & & \\
\hline Total & 24 & 30,4 & 5,8 & & & \\
\hline
\end{tabular}


Jumlah kerapatan spora diperoleh dari hasil pengamatan dengan Haemocytometer di bawah mikroskop, dihitung berdasarkan rata-rata jumlah spora yang diamati dikalikan dengan konstanta dan faktor pengenceran

Tabel 4. Jumlah Kerapatan Spora

\begin{tabular}{|c|c|}
\hline $\begin{array}{l}\text { Perlakuan } \\
\text { Media }\end{array}$ & $\begin{array}{c}\text { Rata-rata kerapatan } \\
\text { konidia } \\
\text { (konidia/mg) }\end{array}$ \\
\hline PDA & $73,3 \times 10^{10} \mathrm{c}$ \\
\hline Beras & $5,53 \times 10^{10} \mathrm{~b}$ \\
\hline Jagung & $5,8 \times 10^{10} \mathrm{~b}$ \\
\hline Kacang Hijau & $0,04 \times 10^{10} \mathrm{a}$ \\
\hline $\begin{array}{l}\text { Serbuk } \\
\text { Gergaji }\end{array}$ & $0,03 \times 10^{10} a$ \\
\hline Dedak & $74,5 \times 10^{10} \mathrm{c}$ \\
\hline \multicolumn{2}{|c|}{$\mathrm{BNT}_{0,05}=1,22$} \\
\hline
\end{tabular}

Pada Tabel 4, dapat dilihat bahwa Trichoderma sp dapat ditumbuhkan pada semua media perlakuan tetapi menunjukkan hasil jumlah konidia yang berbeda. Kerapatan konidia Trichoderma sp tertinggi yaitu pada media dedak sebesar 74,5 x $10^{10}$ konidia/mg tidak berbeda nyata dengan kerapatan konidia pada media PDA yaitu $73,3 \times 10^{10}$ konidia/mg. Pada media jagung kerapatan konidianya tidak berbeda nyata dengan media beras, sedangkan media yang paling rendah terdapat pada media serbuk gergaji sebesar $2,93 \times 10^{8}$ konidia/mg tidak berbeda nyata dengan media kacang hijau yaitu sebesar $3,65 \times 10^{8}$ konidia/mg. Reproduksi aseksual Trichoderma menggunakan konidia. Konidia terdapat pada struktur konidiofor (Samuels, 2010). Hasil penelitian Urailal $d k k$ (2012) bahwa media yang mengandung dedak memberikan pengaruh lebih baik yaitu $7,94 \times 10^{10}$ konidia/ml dibandingkan media kacang hijau dan jagung. Hasil penelitian Novianti (2017), bahwa media dedak adalah media yang paling efektif untuk digunakan sebagai media perbanyakan jamur $M$. anisopliae karena pada setiap variabel pengamatan menunjukkan kemampuan $M$. anisopliae untuk tumbuh dan berkembang yang lebih baik dibandingkan pada media tumbuh lainnya yaitu $120,4 \times 10^{8}$ konidia/mg selama tujuh hari inkubasi). Pertumbuhan Trichoderma sp sangat bergantung pada ketersediaan karbohidrat dan digunakan sebagai sumber energi untuk pertumbuhannya. Bahan yang mengandung karbohidrat dengan konsentrasi tinggi akan mendorong pertumbuhan jamur. Pertumbuhan yang tinggi akan menghasilkan jumlah konidia yang lebih banyak, sedangkan proses pertumbuhan yang rendah akan menghasilkan jumlah konidia lebih sedikit.

\section{KESIMPULAN}

Pertumbuhan Trichoderma sp terbaik didapatkan pada media dedak yaitu menghasilkan diameter koloni $9 \mathrm{~cm}$ dengan kerapatan konidia 74,5 x $10^{10}$ konidia/mg tidak berbeda dengan pertumbuhan pada media PDA sintetik yang di pakai di laboratorium. Media dedak lebih efektif dan efisien untuk digunakan sebagai media perbanyakan Trichoderma $\mathrm{sp}$ dibandingkan media PDA sintetik, beras, jagung, kacang hijau, dan serbuk gergaji.

\section{DAFTAR PUSTAKA}

Alfizar., Marlina., dan Susanti, F. 2013. Kemampuan Antagonis Trichoderma sp Terhadap Beberapa Jamur Patogen In Vitro. J. Floratek 8, 45-51.

Gusnawaty, HS., M, Taufik., dan E, Wahyudin. 2013. Uji Efektivitas Beberapa Media untuk Perbanyakan Agens Hayati 
Gliocladium sp. Jurnal Agroteknos. 3(2), 73-78.

Kansrini, Y. 2015. Uji Berbagai Jenis Media Perbanyakan Terhadap Perkembangan Jamur Beauveria bassiana di Laboratorium. Jurnal Agrica Ekstensia, 9(1), 34-39.

Manokaran, R. 2016. Fast Isolation and Regeneration Method for Protoplast Production in Trichoderma harzianum. https://www.researchgate.net. Diakses 23 Mei 2018.

Miftakhun . 2017. Uji Efektivitas Berbagai Media Selektif Untuk Isolasi Trichoderma spp. Dari Tanah Pada Berbagai Lahan yang Berbeda. Thesis, Universitas Brawijaya. http://repository.ub.ac.id/7089/. Diakses 2 Mei 2018.

Nasahi. 2010. Peran Mikroba Dalam Pertanian Organik. Universitas Pajajaran. Bandung.

Novianti, D. 2017. Efektivitas Beberapa Media untuk Perbanyakan Jamur Metarhizium anisopliae. Jurnal Sainmatika, 14(2), 81-88.

Nurbailis dan Martinius. 2011. Pemanfaatan Bahan Organik sebagai Pembawa untuk Peningkatan Kepadatan Populasi Trichoderma viride pada Rizosfir pisang dan Pengaruhnya terhadap Penyakit Layu Fusarium. Jurnal Hama dan Penyakit Tanaman Tropika, 11(2)

Samuels. 2010. Trichoderma. Systematic Mycologi and Microbiology Laboratory, ARS.USA.
Schuster, A., dan Schmoll, M. 2010. Biology and biotechnology of Trichoderma. Appl Microbiol Biotechnol, 87(3): 787-799.

Shofiyani, A., dan Budi, GP. 2013. Spesies Unggul Trichoderma spp Indigen Rizozfir Pisang Sebagai Pengendali Penyakit Layu Fussarium pada Bibit Tanaman Pisang Mas Hasil Kultur In Vitro. AGRITECH, XV(2),25-40.

Shofiyani dan Suyadi. 2014. Kajian Efektifitas Penggunaan Agensia Hayati Trichoderma sp Untuk Mengendalikan Penyakit Layu Fussarium Pada Tanaman Bawang Merah Diluar Musim. Prosiding Seminar Hasil Penelitian LPPM UMP 2014.

Surtikanti dan Juniarsih. 2010. Pembuatan Formula Pestisida Hayati Beauveria bassiana Vuill dan Kemasannya. Balai Penelitian Tanaman Serelalia. Jakarta.

Suwahyono, U. 2009. Biopestisida. PT. Niaga Swadaya. Jakarta.

Urailal, C., AM, Kalay., E, Kaya., dan A, Siregar. 2012. Pemafaatan Kompos Ela Sagu, Sekam, dan Dedak sebagai Media Perbanyakan Agens Hayati Trichoderma harzianum Rifai. Jurnal Agrologia. 1(1), 21-30.

Wijaya, I., Oktarina., dan Virdanuriza, M. 2011. Pembiakan Massal Jamur Trichoderma sp pada Beberapa Media Tumbuh Sebagai Agen Hayati Pengendalian Penyakit Tanaman. Agritrop Jurnal Ilmu-Ilmu Pertanian. http://digilib.unmuhjember.ac.id/. Diakses 2 Mei 2018. 